\title{
The Analysis of Function and Poetry Content of Traditional Marriage in Seusina Village Community, Sikka Regency
}

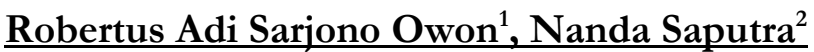 \\ 1,2IKIP Muhammadiyah Maumere, STIT Al-Hilal Sigli, Indonesia \\ Email: robertusadi99@gmail.com, nandasaputra680@gmail.com
}

\section{Abstract:}

This study aims to analyze the function and poetry content of traditional marriage in Seusina Village community, Kewapante District, Sikka Regency, NTT Province. Traditional poetry as an oral tradition contains teachings and values of life that are passed down from generation to generation. The method used in this research is descriptive qualitative with content analysis. Sources of data in the study were informants who met certain criteria and the data in the study were traditional old utterances in the form of word strands that form lines and stanzas. The data validation used the method of triangulation technique, namely by comparing the results of observations in the traditional wedding ceremony of the Seusina Village community. The results showed that the traditional marriage poetry of the Seusina Village community functions as a means of education (didactic) and a means of teaching about good and bad things (morality). The contents of the traditional marriage poetry of the Seusina Village community include strengthening the values of politeness, generosity, patience, and tenacity.

Keywords:

poetry function; poetry content; traditional marriage poetry

\section{Introduction}

Oral tradition is one of the nation's cultural wealth which is now being used as a reference to instill character education in the nation's young generation. This tradition that is still being carried out from generation to generation is a form of local wisdom that is useful for cultivating values. This oral tradition is at the same time considered a folklore passed down from previous generations to the present generation. This is in line with (Cahyani, 2019), (Wahyu Nengsih Balai Bahasa Kalimantan Selatan \& Yani KM, n.d.), (Owon, 2017) which basically says that local wisdom is the conclusion of the various habits of the human community from a certain area as a cultural heritage that is developed because it contains messages, moral teachings, and certain characteristics.

Oral tradition is interpreted as oral literature which is spoken by word of mouth whose existence has begun to be eroded by advances in science and technology. Delivery of messages and entertainment media are replaced by these technologies. This is in line with (Ita Khairani \& Andin Nur Sinaga, 2020), (Suantoko, 2016) which emphasizes that oral literature exists and develops in societies whose enthusiasts are long before they know written literature. The shift in local culture due to the entry of foreign cultures has made the existence of oral literature almost extinct. Oral literature, which used to play an important role as a means of entertainment for the community, is now being replaced by technological sophistication.

One of the oral traditions that developed until now is poetry. In the realm of Indonesian literature, poetry is one of the old types of poetry that exists and develops throughout the archipelago. Poetry is essentially an old form of poetry consisting of 4 separate 


\section{Linglit Journal: Scientific Journal of Linguistics and Literature \\ ISSN: 2774-4523 (Online), 2774-4515 (Print) \\ Vol. 2, No. 1, March 2021, Page: 17-24 \\ Email: linglitjournal@gmail.com}

lines, straight rhymes, containing the contents of each line which is a series of stories. This old poem contains various messages and moral teachings that can be used as a guide for life. Character education can be started from analyzing the lyrics that develop in the community as local wisdom. This is in line with (Daulay et al., n.d.), (Saraswati, 2019), (Ita Khairani \& Andin Nur Sinaga, 2020) which emphasizes that local wisdom including poetry contains educational values which include (1) religious educational values, (2) educational values of resilience, (3) educational values of care, and (4) educational values of honesty.

Poetry in the oral tradition of Seusina Village community, Kewapante District, Sikka Regency is known as kleteng latar. Kleteng latar is used as a means of delivering effective messages from the older generation to the younger generation. This oral tradition is also used in certain ethnic wedding ceremonies in Sikka Regency, including Seusina Village community. The traditional marriage ceremony in this area is used as a sacred moment to validate the status of a partner.

The poetry or kleteng latar in traditional society represents the values of society which are manifested in the form of background behavior references. This is in line with (Malaon, 1986) which states that the oral tradition or kleteng latar is a product of transmission from generation to generation, usually transferred through spoken or written language, even by ceremonies, which contain ideas, feelings, and values associated with group life social. In it contains various values that can be guided as a reference for society in behavior that gives birth to traditions and culture that are part of the norm. Thus, culture is seen as the work of humans that thrive in tune with the development of civilization (Sartini, 2009), (Danandjaja, 2007).

Sari et al (2020) stated that According to Kazeem (2020) Language is an integral part of culture, a reflection of many features of a given culture. Thus, like culture itself, language is a learned behavior, which can be enhanced through direct or indirect contact. The question around the features of second language poetry lies at the heart of this research. What is defined by the term "second language poetry"? Hanauer (2010) in his research about exploring second language poetry has formulated some characteristics of second language poetry. Giving new meaning to what has been experienced or will be experienced in a way that is more than habitual, may make us realize that this is what the poet or novelist is meant to be in certain parts of which we have not yet fully understood (Srinarwati, 2018).

In the community of Seusina Village, the traditional wedding ceremony as a cultural heritage is still considered relevant to transfer the values of life to the younger generation, namely a married couple. The bride and groom must go through a traditional marriage rite before living as husband and wife in one family. The delivery of messages to the bride and groom is marked by the provision of food and drink in the symbol of a pig's heart and moke (a typical liquor from Sikka Regency). These two types of food and drink are symbols of unity and constancy in married life. While feeding food and drinks, the traditional elder chants the traditional poetry as a mandate or message that will be used as a living provision for the bride and groom in fostering their household.

Based on this, it is necessary to conduct a study of the poetry of the Seusina Village community as reinforcing the value of community identity. This research focuses on the function and content of traditional marriage poetry in the area. The function of poetry is based on the function of literary works as aesthetic, recreational, didactic, religious, and moral means. It is hoped that this study will have benefits for the world of education, guidance, and development of regional languages. 


\section{Research Methods}

This study intends to identify the function and content of traditional marriage poetry through a qualitative approach. The method used in the discussion is descriptive qualitative. This research was conducted in Seusina Village, Kewapante District, Sikka Regency, East Nusa Tenggara. The data of this research are in the form of spoken utterances in the form of word strands from poet speakers. The data sources of this study were informants whose criteria were determined based on the criteria of linguistic informants, namely those who met the requirements as elder figures in society: over 50 years of age, mastering the intricacies of old poetry, mastering local languages, and having sufficient time. Data collection is carried out by using observation and participant observation techniques which are used to collect data through what is captured by the senses, namely that the researcher is really there with the resource person (Sudaryanto, 1993), (Rahmat, 2009). The data validation was done by triangulation by observing text messages based on the sense of hearing, sense of taste, and sense of sight (Eriyanto, 2011).

\section{Results and Discussion}

The traditional marriage of the Kopong Village community consists of 3 stages which include the opening stage, the main ceremony, and the ceremony for entering the bridal chamber. In the opening stage, the traditional elder sits cross-legged opposite the bride and groom while reciting the following verse:
Miu du'a ba'a giit
Wahai dikau wanita dewasa
Giit ba'a meti lepo
Wanita penjaga rumah tangga
Miu mo'an ba'a mangan
Mangan ba'a plamang woga
Wahai dikau pria mapan
Pria pahlawan keluarga

At the core ceremony stage, the adat elder does 3 things with 3 stanzas that accompany it. These three things are:

1. The traditional elder took the liver of the pig and moke, then fed the bride and groom, while saying the following words:
Gea sai wawi api ara plangan
Makanlah hati babi dan nasi
Dena jaji wai nora la'in
Sebagai pengikat janji suami istri
Minu sai tua gahu supa
Minumlah moke panas
Dena supa lihan nora lalan
Sebagai sumpah sehidup semati

2. The traditional elder sprinkles flowers on the bride, while saying the following words:
Wuat naha baka lika
Berbuah banyak dan ranum
Puhut naha jiro jaro
Berbunga indah semerbak mewangi
Bua buri ganu wetan
Lahirkanlah anak sebanyak mungkin
Gae teto ganu atong
Sebanyak sewawut dan bayam

3. The traditional elder sprays yellow rice on the body of the bride, while chanting the following verses:
Deri le'u nete eting
Gera le'u nete oang
Sape kang benu wuli
Sape wodong lu'u wai
Penuhilah bumi sampai pelosok
Berdirilah hingga di sudut kampung
Hingga dunia ini penuh terisi
Sampai tanah ini tek tersisa 
In the last stage, the traditional elder gives advice in the bridal chamber with the following verses:

Ata du'a ba'a giit meti lepo

Naha tutur gepu ganu hepun

Ganu hepun papan unen

Lopa tutur dete wawa lean blon

Odi tilu riwun wawa diri rena

Odi wae meang ganu mate

Au mo'an ba'a mangan plamang woga

Naha harang blebo ganu hewon

Ganu hewon tua wutun

Lopa harang wawa lasa lawing

Odi mata ngasun wawa ni'a ita

Odi mata berat ganu bunu

Gou naha lau leman

Gou mai saing wain

Bata naha reta tana maran

Bata mai toma men

Nian poa lero ha'e

Reging sai taka, rema sai poron

Gopi sai roin, lema sai kabor

Kare sai tua peni sai manu

Dena bihing wain botik men

Nian waunlero wawa

Ait naha mai degu lewu

Wair naha mai hading ata

Saing wain toma men

Nian poa lero ha'e

Bu'ut sai buhar, rema sai ehar

Jata sai kappa moru lorun

Dena sapu la'in pelang men

Nian waun lero wawa

Api naha bara damar naha nilo

Utat naha blain, wair naha gahu

Dena api al'in gahu men
Wahai wanita penjaga rumah

Berbicaralah yang halus dan santun

Seperti suara nyamuk di dalam tempurung

Jangan berteriak panjang lebar

Nanti ratusan telinga mendengar

Kalian akan malu bagai mati

Wahai pria pahlawan keluarga

Nasihatlah yang halus budi bahasa

Seperti kumbang di pucuk lontar

Jangan marah hingga kalap

Nanti ratusan mata turut melihat

Kalian akan tertunduk bagai mati

Carilah rezeki di tengah laut

Bawalah pulang untuk istrimu

Temukan nafkah di daratan

Bawalah pulang untuk anakmu

Jika matahari beranjak naik

Ambilah tofa dan parang

Bukalah hutan, tanamlah kelapa

Sadaplah moke peliharalah ayam

Untuk menghidupi istri dan anak

Jika petang menjelang malam

Kayu api harus kau bawa

Air harus pula tersedia

Untuk istri dan anakmu

Jika pagi hari mulai menjelang

Ambillah perlengkapan ikat tenun

Pintallah benang tenunlah kain

Untuk suami dan anakmu

Jika malam menjelang tiba

Dapurmu harus berasap

Sediakan makanan dan minuman

Untuk suami dan anakmu

The traditional marriage poetry of the Seusina Village community contains several functions, including the following: 


\subsection{The Function of the Traditional Marriage Poetry of the Seusina Village Community}

a. The Function of Poetry as a Means of Education (Didactic)

The didactic function means an orderly and well thought out way to achieve goals or a systemized way of working to facilitate activities in order to achieve the desired goals (Big Indonesian Dictionary). Based on this meaning, traditional marriage poetry which is in line with this includes:

Nian poa lero ha'e

Reging sai taka, rema sai poron

Gopi sai roin, lema sai kabor

Kare sai tua peni sai manu

Dena bihing wain botik men
Jika matahari beranjak naik

Ambilah tofa dan parang

Bukalah hutan, tanamlah kelapa

Sadaplah moke peliharalah ayam

Untuk menghidupi istri dan anak

In part of these verses, you can find work methods or procedures in the world of agriculture, namely when starting work (line I), preparation of tools and materials (array II), how to work (lines III and IV), and work results (array V). Thus, traditional marriage poetry fulfills its function as a means of education and teaching for the groom. The same is applied to the bride in the following verse:

Nian poa lero ha'e

Bu'ut sai buhar, rema sai ehar

Jata sai kappa moru lorun

Dena sapu la'in pelang men
Jika pagi hari mulai menjelang

Ambillah perlengkapan ikat tenun

Pintallah benang tenunlah kain

Untuk suami dan anakmu

In part of these verses, you can find work methods or procedures in the home industry, namely when you start work (line I), preparation of tools and materials (line II), how to work (line III), and work results (line IV). Thus, traditional marriage poetry fulfills its function as a means of education and teaching for the bride.

\section{b. The Function of Poetry as A Teaching Regarding Good and Bad (Morality)}

Morality in this case is defined as everything related to etiquette or customary courtesy. Etiquette or customary courtesy in traditional marriages is related to communication procedures. By (Muslikhah et al., n.d.) communication will be effective if the communicator appreciates each individual, person or group that is the target of communication. This requires that a person who communicates can place himself, not consider himself to be the most knowledgeable and truest person. This is illustrated in the following verse:

\begin{abstract}
Ata du'a ba'a giit meti lepo
Naha tutur gepu ganu hepun

Ganu hepun papan unen
\end{abstract}

Au mo'an ba'a mangan plamang woga

Naha harang blebo ganu hewon

Ganu hewon tua wutun
Wahai wanita penjaga rumah

Berbicaralah yang halus dan santun

Seperti suara nyamuk di dalam tempurung

Wahai pria pahlawan keluarga

Nasihatlah yang halus budi bahasa

Seperti kumbang di pucuk lontar

In the two verses of the verse, it can be seen that both the groom and the bride have to build a polite relationship which is characterized by speaking smooth words and good language. The soft sound is symbolized by the sound of mosquitoes in the shell and beetles on the palms of the palms. If this condition is maintained, the existence of the household will be maintained and become a role model for the surrounding family. 


\subsection{The Contents of the Traditional Marriage Poetry of Seusina Village community}

a. Traditional Marriage Poetry to Reinforce the Value of Politeness

Seusina Village community are expected to have good manners between one another. Politeness is a determining factor for success in building a relationship. The most special relationship is the relationship as husband and wife. For this reason, a married couple must maintain the norms of decency in building a married life. The value of politeness can be seen in the following verse:

Lopa tutur dete wawa lean blon

Odi tilu riwun wawa diri rena

Odi wae meang ganu mate
Jangan berteriak panjang lebar

Nanti ratusan telinga mendengar

Kalian akan malu bagai mati

Some of the traditional poetry was intentionally conveyed to the bride and groom in terms of speaking the language and greeting them. The bride and groom are expected to solve problems in the household politely so that they do not become the subject of the neighbors' gossip because it would be very embarrassing.

\section{b. Traditional Marriage Poetry to Reinforce the Value of Endurance}

In general, Seusina Village community work as farmers. This profession demands patience in doing it. Farmers cannot immediately harvest their agricultural products in a short time. For that, patience is needed in waiting for the plants to produce results. This is illustrated in the following traditional marriage verse:

Nian poa lero ha'e

Reging sai taka, rema sai poron

Gopi sai roin, lema sai kabor

Kare sai tua peni sai manu

Dena bihing wain botik men
Jika matahari beranjak naik

Ambilah tofa dan parang

Bukalah hutan, tanamlah kelapa

Sadaplah moke peliharalah ayam

Untuk menghidupi istri dan anak

This verse was deliberately conveyed to the groom to cultivate land to support his household. Plants that are required to be cultivated are long-lived coconuts to give fruit. This requires courage in waiting for the harvest. In addition, in making a living for the necessities of daily life, fortitude is also needed. This is illustrated in the following verse:

Gou naha lau leman

Gou mai saing wain

Bata naha reta tana maran

Bata mai toma men
Carilah rezeki di tengah laut

Bawalah pulang untuk istrimu

Temukan nafkah di daratan

Bawalah pulang untuk anakmu

This verse contains the value of courage because you have to go to sea to earn a living. Working as a fisherman requires courage and patience in waiting for the hook or net to be caught.

\section{c. Traditional Marriage Poetry to Reinforce the Value of Volunteerism}

One of the characteristics of Seusina Village community and villages in general is to prioritize solidarity in a family spirit. People are required to help each other in joy and sorrow. The attitude required is to give and share. This is reflected in the following verse:

Nian waun lero wawa

Api naha bara damar naha nilo

Utat naha blain, wair naha gahu

Dena api al'in gahu men
Jika malam menjelang tiba

Dapurmu harus berasap

Sediakan makanan dan minuman

Untuk suami dan anakmu 
The verse shows the generous people of Seusina Village. This is indicated by a message sent to the bride to prepare and serve food for her husband and children. Solidarity is the main demand and eliminates selfishness wherever possible.

\section{d. Traditional Marriage Poetry to Reinforce the Value of Tenacity}

Seusina Village community are hardworking people. This can be seen from their main livelihood as a farmer. This work demands a high level of tenacity and tenacity. For this reason, a similar message was given to the bride and groom before entering married life. The traditional marriage verse verse that is in line with it is: As a migrant, one demands persistence in working in order to collect a lot of money and goods. This is reflected in the following verse:
Nian poa lero ha'e
Reging sai taka, rema sai poron
Gopi sai roin, lema sai kabor
Kare sai tua peni sai manu
Dena bihing wain botik men

Jika matahari beranjak naik

Ambilah tofa dan parang

Bukalah hutan, tanamlah kelapa

Sadaplah moke peliharalah ayam

Untuk menghidupi istri dan anak

This verse indicates that Seusina Village community always never give up in cultivating agricultural land to live in the future. The groom has to work all day long from the sun rising until the sun falls into the night. This indicates the high value of tenacity and persistence in fighting for life.

\section{Conclusion}

Based on the results and discussion, it can be concluded that the traditional marriage poetry of Seusina Village community has a function as a means of education (didactic) and a means of teaching morals related to good and bad things (morality). Recreational, aesthetic, and religious functions are not found in the traditional marriage poetry of Seusina Village community. The content of the traditional marriage poetry of Seusina Village community is to reinforce the values of politeness, the value of patience, the value of tenacity, and the value of generosity.

\section{References}

Cahyani, M. (2019). Analisis Kearifan Lokal Novel Bidadari Bermata Bening Karya Habiburrahman El Shirazy Dan Rencana Pelaksanaan Pembelajarannya Di Kelas XII SMA. In Genre (Vol. 1, Issue 1). http://journal2.uad.ac.id/index.php/genre/index

Danandjaja, J. (2007). Folklor Indonesia: Ilmu gosip, dongeng, dan lain-lain.

Daulay, I. R., Ws, H., \& Manaf, N. A. (n.d.). Nilai-Nilai Edukatif Dalam Lirik Nyanyian OnangOnang Pada Acara Pernikahan Suku Batak Angkola Kabupaten Tapanuli Selatan Provinsi Sumatera Utara.

Eriyanto. (2011). Analisis Isi: Pengantar Metodologi untuk Penelitian Ilmu Komunikasi dan Ilmu-ilmu Sosial Lainnya Kencana (p. ix + 510). http://journal.ui.ac.id/index.php/jkmi/article/viewFile/7832/3899

Hanauer, D.I., 2012. Meaningful literacy: Writing poetry in the language classroom. Language Teaching, 45(1), pp.105-115.

Ita Khairani, \& Andin Nur Sinaga. (2020). Educational Values in the Kaba Minangkabau Text "Anggun Nan Tongga Si Magek Jabang." Lakhomi Journal Scientific Journal of Culture, 1(1), 15-22. https://doi.org/10.33258/lakhomi.v1i1.339 
Kazeem, A. S. and Suleiman, M. I. (2020). Prospects and Problems of Language Policy to Indigenous Languages in Nigeria. Britain International of Linguistics, Arts and Education Journal. 2(1): 330-337.

Malaon, T. I. dkk. (1986). Mengengok Tradisi: Sebuah Alternatif bagi Teater Modern. Dewan Kesenian Jakarta Lembaga Studi dan Riset Mahabudhi Indonesia.

Muslikhah, O.:, Disampaikan Pada Kegiatan, D., Kepada, P., Tahun, M., Penyuluhan, ", Yang Efektif Bagi Guru, K., Di, T. K., Panjatan, K., \& Pendahuluan, " A. (n.d.). Komunikasi Yang Efektif.

Owon, R. A. S. (2017). Pengembangan Bahan Ajar Menulis Sastra Indonesia di SMP. Jurnal Inovasi Pembelajaran, 3(1), 528-541.

Rahmat, S. P. (2009). Penelitian Kualitatif. Equilibrium, 5, 1-8.

Saraswati, E. (2019). The Cultural Capital and Strategy of Indonesian Poets in the 2000s.

Sari, W.S., et al. (2020). Facilitating Novice Writers with Creative Writing Workshop in Poetry Writing Classroom (Indonesian EFL Context). Budapest nternational Research and Critics in Linguistics and Education (BirLE) Journal, 706-713.

Sartini, N. W. (2009). Menggali Nilai Kearifan Lokal Budaya Jawa Lewat (Bebasan, Saloka, Dan Paribasa). Jurnal Logat, 5(1), 28-37.

Srinarwati, D.R. (2018). The Disclosure of Life Experience and Its Expression in Cultural Studies Perspective. Budapest International Research and Critics Institute (BIRCI Journal) : Humanities and Social Sciences. 1(2); 125-141.

Suantoko, S. (2016). Fungsi Sastra Lisan "Tanduk" Masyarakat Genaharjo Kabupaten Tuban Bagi Masyarakat Pendukungnya. Jurnal Pendidikan Bahasa Dan Sastra, 16(2), 246. https://doi.org/10.17509/bs_jpbsp.v16i2.4486

Sudaryanto. (1993). Metode dan aneka teknik analisis bahasa: pengantar penelitian wahana kebudayaan secara linguistis. Duta Wacana Universty Press. https://opac.perpusnas.go.id/DetailOpac.aspx?id=196071

Wahyu Nengsih Balai Bahasa Kalimantan Selatan, S., \& Yani KM, J. A. (n.d.). Kearifan Lokal Dalam Legenda Keagamaan Masyarakat Banjar (Local Wisdom In The Banjar Community Religious Legends). In Sastra dan Pembelajarannya (Vol. 10, Issue 1). 